\title{
Congressional Decision Making and the Separation of Powers
}

\section{ANDREW D. MARTIN Washington University in St. Louis}

\begin{abstract}
70 what extent does the separation of powers affect congressional roll call voting behavior? To answer this question, I offer a strategic model of congressional decision making that asserts members of Congress pursue public policy goals when casting roll call votes. From the equilibrium predictions of a formal model, I generate testable hypotheses by computing the expected net amount of sophisticated (nonsincere) congressional behavior given changes in decision context. I test the predictions of the theoretical model with data from all civil rights roll call votes from the $83 d$ to the $102 d$ Congress. The results demonstrate that both the other legislative chamber and the Supreme Court profoundly constrain House members and senators when casting roll call votes. This is strong evidence of the importance of policy outcomes to members of Congress when voting on the floor.
\end{abstract}

W hen building (and later trumpeting) their legislative accomplishments, members of Congress refer both to the votes they cast and the public policy enacted during their watch. If Congress acted alone in the policymaking process, these actions would be one and the same. Yet, because of the separation of powers, taking a position by casting the right vote may come in conflict with pursuing the right policy outcome. This is because policy is not formed by Congress alone in a system characterized by the separation of powers, but in conjunction with the president and the Supreme Court. Indeed, voting for a specific bill does not guarantee the outcome prescribed in the legislation because the president and the courts can review the established policy.

A foundational assumption of congressional research is that members of Congress pursue reelection (Mayhew 1974). To do so, Mayhew argues that members of Congress advertise (create a favorable image through behavior devoid of issue content); claim responsibility "for causing the government, or some unit thereof, to do something [desirable]" (p. 52); and take positions on various issues of the day. Clearly, members of Congress use all these behaviors to pursue reelection. Yet, in an institutional context, there may be an inconsistency between the credit-claiming and position-taking strategies.

When casting a roll call vote, a member of Congress may simply be seeking to go on the record for or against a particular policy, or she may be interested in claiming credit for a tangible policy outcome. On the

Andrew D. Martin is Assistant Professor of Political Science, Washington University, Campus Box 1063, One Brookings Drive, St. Louis, MO 63130.

An earlier version of this article was presented at the American Political Science Association annual meeting, Boston, Massachusetts, September 3-6, 1998. I am grateful to Brady Baybeck, Cliff Carrubba, Sid Chib, Lee Epstein, Jack Knight, Gary Miller, Carla Molette-Ogden, Kevin Quinn, John Sprague, Greg Wawro, Christina Wolbrecht, and the anonymous reviewers for commenting on various aspects of this project; to Keith Poole for providing Nominate data; and to the Center in Political Economy at Washington University for financial support. All remaining errors are my sole responsibility. Supplementary materials are available on the author's homepage: http://adm.wustl.edu/replicate.html. These materials include results from alternative model specifications, my selection of civil rights roll calls, all data necessary to replicate the study, and GAUSS code to estimate the statistical models. one hand, a member of Congress interested in taking a position can always vote sincerely for her most preferred policy. On the other hand, if policy outcomes are important, she cannot always vote her preference because Congress, the president, and the Supreme Court work together to form public policy (Eskridge 1991; Marks 1989). Thus, if members want to claim credit for policy change, they must be mindful of the separation of powers. As I argue below, adopting a credit-claiming strategy rather than simply taking a position can lead to profoundly different congressional behavior under certain circumstances. For example, had supporters of the Violence Against Women Act of 1994 voted for a more moderate bill, it is possible the Supreme Court would not have struck down the civil damages provision. In this case, the final policy was significantly different from the bill passed by Congress and signed by the president.

My purpose is to examine the effect of the separation of powers on congressional behavior. I address two questions that are inextricably related. First, does the separation of powers affect congressional roll call voting behavior? Second, when members of Congress cast roll call votes are they motivated by a desire solely to take a position, or both take a position and claim credit? I begin with a brief review of the literature, highlighting the predominant assumption of sincere behavior. I then posit a formal model of congressional decision making and the separation of powers, from which I generate hypotheses about congressional behavior. Next, I focus on research design, in particular case selection, measurement, and statistical issues. This section is followed by an analysis of roll calls on civil rights bills from the $83 \mathrm{~d}$ to the $102 \mathrm{~d}$ Congress. The results demonstrate that both House members and senators are systematically and significantly constrained by the separation of powers in their roll call behavior; that is, they take positions and strategically claim credit with their roll call votes. I conclude with a discussion of the implications of this research.

\section{CONGRESSIONAL GOALS: VOTES OR POLICY?}

The literature is rich with discussions of congressional goals. Some authors posit a strict reelection goal 
(Arnold 1990; Fiorina 1974; Mayhew 1974), and others argue for multiple goals (Fenno 1973; Kingdon 1989), such as reelection, intra-Washington influence, and obtaining good public policy. Members of Congress pursue these goals in many different ways, one of which is through their roll call votes.

\section{The Policy Dimension Theory}

The policy dimension theory of decision making is reflected in the scaling literature of the 1950s and 1960s (see, e.g., Belknap 1958; Miller and Stokes 1963). Clausen $(1973,14)$ provides a theoretical foundation:

The policy dimension theory states that legislators reduce the time and energy requirements of policy decisionmaking by (1) sorting specific policy proposals into a limited number of general policy content categories and by (2) establishing a policy position for each general category of policy content, one that can be used to make decisions on each of the specific proposals assigned to that category.

Thus, for a single dimension, the theory predicts that individuals have a preferred position (derived from a multitude of factors), and they make choices based on that position.

\section{The Ideological Model}

In the late 1970 s a separate literature emerged and asserted the existence of one (or more) ideological dimensions that structure all congressional voting. This ideological model contends that members of Congress "make their policy choices on the basis of some internalized set of political values and beliefs about the world" (McCormick and Black 1983, 45). Poole and Rosenthal (1997) demonstrate that one predominant (and occasionally a second) dimension has structured American politics for more than two centuries. In many different policy areas there is a strong relationship between ideology and congressional roll call votes (e.g., Kau and Rubin 1979; Richardson and Munger 1990; Segal, Cameron, and Cover 1992). The difference between the policy dimension theory and the ideological model concerns dimensionality, but both are consistent with the spatial voting model (Downs 1957; Enelow and Hinich 1984). The spatial model contends that members of Congress have a fixed policy preference and vote for the option closest to them in an ideological space; that is, members of Congress vote sincerely, which is consistent with a position-taking strategy.

The question remains as to whether members of Congress just take a position with their roll call votes or also strategically pursue policy outcomes to facilitate credit claiming. Credit claiming and position taking often are manifested in identical voting patterns, but in other cases strategic members of Congress may vote for a less preferred policy at the roll call stage to get better policy after review by the president and the Supreme Court. The null hypothesis for this research is that members of Congress exclusively take positions with their roll call votes and hence are not constrained by the separation of powers. As noted earlier, if supporters of the Violence Against Women Act of 1994 had chosen an alternative remedy instead of civil damages, it is likely that the Court would not have struck down the enforcement provisions of the bill. In other words, voting for a less preferred bill could have produced a preferable policy outcome. The alternative to the null is that members of Congress take position and claim credit when voting on the floor, that is, behave strategically.

\section{THEORY AND HYPOTHESES}

To isolate the circumstances when position-taking and credit-claiming behavior differ, I construct an account of congressional decision making under the separation of powers. My explanation departs from the literature in that I assume members of Congress strategically pursue public policy in the separation of powers system.

\section{Assumptions}

The first assumption is that members of Congress pursue policy goals when voting on the floor. A number of factors may shape policy preference, including personal goals, ideological goals, or instrumental goals of satisfying constituents or a particular interest group. Yet, as argued by Clausen (1973), in whatever manner these competing interests are weighed in the congressional mind, members have a preferred policy position that they hope to pursue with their votes on the floor. This account is consistent with the notion of an induced preference; that is, policy preferences held by members of Congress may not be personal but are induced by external factors, such as constituents or interest groups. The assumption of goal-seeking behavior pervades models of congressional decision making (Clausen 1973; Kingdon 1989; Mayhew 1974; Poole and Rosenthal 1997). ${ }^{1}$

The second assumption is that policy outcomes matter to members of Congress. The strategic account asserts that they are not as concerned with the outcome of a particular vote as they are with the final policy that emerges from the separation of powers system (Arnold 1990). Citizens in our democracy are profoundly affected by public policy, not individual roll call votes; public policy, implemented by the executive branch and refined by future Congresses and the Supreme Court, is what pertains to their lives. Thus, to pursue reelection and other legislative goals, it is reasonable to assume that members of Congress are concerned with the ultimate state of public policy. ${ }^{2}$

\footnotetext{
${ }^{1}$ In certain circumstances constituents with spatial preferences may produce a majority cycle, which yields no unique preference for the member of Congress (Bianco 1994; McKelvey 1979), who then may pursue policies to achieve other, nonconstituent goals. The argument presented below turns on whether members of Congress have single-peaked preferences, not on whether these are derived from constituencies or some other factor (Clausen 1973).

2 To use credit claiming in a campaign, members of Congress must realize a tangible policy outcome. Yet, strategic members of Con-
} 
The final assumption is that members of Congress are strategic. Simply put, they rationally pursue public policy in an interdependent choice setting. Nearly all legislation that passes Congress must be signed or vetoed by the president, and the Supreme Court has the power of judicial review. Thus, any policy decision made by Congress is preliminary. In the end, public policy may be quite different from the bill Congress passes. Implicit in this assumption is the notion that none of the branches has the final say on public policy. Indeed, legislation can be overturned by the Court (on statutory or constitutional grounds), and its decisions can be overturned by Congress and the president, including those decided on constitutional grounds (Eskridge 1991; Murphy 1964; Rosenberg 1992). Because legislative majorities are always changing, and because legislating is inherently costly, strategic members of Congress should be mindful of the other branches, including the Court, when casting roll call votes. I thus assume that congressional voting is consistent with the equilibrium of the model presented below.

\section{The Separation of Powers Model}

The separation of powers game is played by four actors: a member of Congress, the median member of Congress in the other chamber, the president, and the median justice of the Supreme Court. I make three assumptions. First, each political actor has well-defined and stable preferences on a policy continuum. Actors derive utility exclusively from policy; the closer is the policy outcome to their ideal point, the more utility they receive. This implies that each actor's utility function is single-peaked. Second, all players have complete and perfect information about the bliss points of the member of Congress voting on the proposal, the median member of the other chamber, the president, and the median Supreme Court justice. ${ }^{3}$ Third, the game is played in a unidimensional policy space on the unit interval. By assumption, the policy alternative is to the left of that status quo $(A<Q) .{ }^{4}$

The game proceeds as follows. The member of Congress (whose bliss point is denoted $x_{c}$ ) moves first and must vote for one of two exogenously fixed choices: an alternative $A$ or the status quo $Q$. If the member votes for the status quo, the game ends, and policy does not change (with policy outcome $Q$ ). If the member votes for the policy alternative, the bill proceeds to a conference, where a compromise with the median member of the other chamber (bliss point $x_{o}$ ) yields a

gress may not realize their preferred outcome because of presidential and judicial review. Even if a policy is not ultimately realized, its pursuit will yield strategic congressional behavior.

3 "Bliss point" will be used interchangeably with preferred policy position.

${ }_{4}^{4}$ This assumption is purely historical. In the civil rights policy domain, most new proposals have been to the left of the status quo (although some votes were cast on conservative amendments). In the data analysis presented below, all votes are coded such that this assumption holds. revision $\left(x_{o}+A\right) / 2.5$ The compromise bill proceeds to the president (bliss point $x_{e}$ ), who must sign or veto it. If the president vetoes the legislation, the game ends, and policy does not change (the outcome is $Q$ ). ${ }^{6}$ If the president signs the bill, the legislation is then subject to judicial review by the median Supreme Court justice (bliss point $\left.x_{j}\right){ }^{7}$ The Court can overturn the entire bill (returning policy to $Q$ ), overturn parts of it (resulting in an outcome located anywhere in the region bounded by $\left(x_{o}+A\right) / 2$ and $Q$ ), or do nothing (making the bill signed by the president the final policy outcome $\left(x_{o}+\right.$ $A) / 2$. Once the game is over, the policy outcome is determined, and payoffs are assigned by simple quadratic utility functions. ${ }^{8}$

\section{Hypotheses}

Testing predictions of formal models is a difficult task, fraught with epistemological challenges (as cautioned by Green and Shapiro [1994] and their subsequent critics). Typically, one finds the equilibria of a model and checks to see if the behavioral predictions are observed. This strategy is quite arduous because each parameter of the model must be measured on the same scale without error, due to the knife-edge cut points that often characterize the equilibria. In addition, one needs to observe multiple realizations of the game with varying parameter values to test comparative statics results. In most observational settings, neither of these is empirically feasible.

To overcome these problems and generate directly testable hypotheses, I take a different approach. I begin by making behavioral predictions for both the strategic and nonstrategic accounts, and I then exploit the observable differences between these types of behavior. These occur when members of Congress are observably nonsincere (termed by Krehbiel and Rivers [1990, 549] "empirically identifiable sophisticated behavior"). ${ }^{9}$ I average over the distribution of congressional bliss

\footnotetext{
5 Many times, such as with the Civil Rights Act of 1957 and the Civil Rights Act of 1964, bills not in agreement bypass the conference stage, as the leadership can gain passage for a compromise bill in both chambers.

${ }^{6}$ If the president vetoes the bill, it is certainly plausible that Congress will pass another. This occurred when President Bush vetoed the Civil Rights Act of 1990. Congress then passed a compromise bill, which became the Civil Rights Act of 1991. The second piece of legislation, however, is another realization of the separation of powers game, as is a veto override attempt (without presidential review).

${ }^{7}$ Only four of the nine justices are needed to grant certiorari. For a precedential decision to be reached, however, a majority is needed. 8 The model assumes that the member of Congress believes with nonzero probability that (1) she is pivotal on the particular vote and (2) a compromise bill will always emerge from conference. These are certainly tenuous assumptions. Yet, if a member thinks she is not pivotal or that the conference committee will never report a compromise, then she is free to take a position and cast a sincere vote. This biases all empirical results in the proper direction toward the null hypothesis of sincere behavior.

${ }^{9}$ I will employ the term "sophisticated" to denote observably sophisticated (nonsincere) behavior. There is a formal theoretical and applied literature that documents sophisticated voting in Congress over agendas (see Calvert and Fenno 1994; Enelow and Koehler 1980; Volden 1998; c.f. Krehbiel and Rivers 1990). Rather than look
} 
points, which yields predictions about the net amount of sophisticated congressional behavior for a particular decision context. From these I generate testable hypotheses about the net amount of sophisticated congressional behavior as a function of political decision context (see Martin 1998).

I characterize the subgame perfect Nash equilibrium of this simple game using backward induction, deriving a function $\sigma_{c}^{*}\left(x_{c}, x_{o}, x_{j}, x_{e}\right)$ that produces the equilibrium congressional strategy, given the member's bliss point and the political context (Martin 1998). To form a baseline for comparison, one can define a similar function for a nonstrategic member of Congress. Because nonstrategic actors do not take into account the decision context when casting votes, they always behave sincerely; that is, they vote for the policy option they most prefer. Given the assumption that $A<Q$, the function $\Psi\left(x_{c}\right)$ predicts votes for the nonstrategic account:

$$
\Psi\left(x_{c}\right)=\left\{\begin{array}{lll}
0 & \text { if } & 0 \leq x_{c} \leq(A+Q) / 2 \\
1 & \text { if } \quad(A+Q) / 2<x_{c} \leq 1
\end{array} .\right.
$$

This function implies that a member of Congress will vote for the option closer to her bliss point; if she falls to the left of the cutpoint, she votes for $A$, and if she falls to the right, she votes for $Q$. Note that $\sigma_{c}^{*}(\cdot)$ is a function of the policy preferences of the member of Congress and the other actors that define the decision context, whereas $\Psi(\cdot)$ is only a function of the bliss point of the member of Congress. To compare the strategic and nonstrategic models, one must compare the predictions of $\sigma_{c}^{*}(\cdot)$ and $\Psi(\cdot)$.

For many members of Congress in a particular decision context, the strategic model $\sigma_{c}^{*}(\cdot)$ and the nonstrategic model $\Psi(\cdot)$ predict precisely the same behavior. For others, however, they differ. The equilibrium predictions of the formal model show that sophisticated (nonsincere) behavior will occur in the following case. Suppose we have a moderate/conservative member of the House faced with the prospect of voting for or against a civil rights proposal. He sincerely prefers the status quo to the policy alternative, but since the players in the rest of the separation of powers system are moderate (compared to the status quo), he can vote for the liberal policy with the confidence that more moderate-and thus more preferable-policy will emerge in the end. This is illustrated in the sophisticated voting areas in Figure 1. In other words, a moderate can vote for a bill that is too liberal on its face with the expectation that, at the end of the game, the ultimate policy will be more moderate because of executive and judicial review.

To compare the behavioral predictions of the two explanations, one must compute the difference between these functions. For a particular member of Congress in a particular decision context, the absolute value of the difference between $\sigma_{c}^{*}(\cdot)$ and $\Psi(\cdot)$ equals 1 if she is acting in a sophisticated manner, 0 otherwise. Assuming a fixed proper distribution of congressional

at agenda setting, however, I focus here on sophisticated behavior with respect to the separation of powers. preferences $f\left(x_{c}\right)$ supported on the unit interval, one can write the following composite function:

$$
s\left(x_{o}, x_{e}, x_{j}\right)=\int_{0}^{1}\left|\sigma_{c}^{*}(\cdot)-\Psi(\cdot)\right| f\left(x_{c}\right) d x_{c} .
$$

The function $s(\cdot)$ averages over the distribution of bliss points and provides the net amount of sophisticated congressional behavior for a particular decision context, parameterized only by the measures of political context. To generate testable hypotheses, I perform comparative statics on this net sophisticated voting function $s(\cdot)$ (Martin 1998). By determining whether this function is increasing or decreasing in the parameters that measure political context, one can predict changes in the net amount of sophisticated congressional behavior.

The first analysis concerns the median member of the other chamber. I am interested in how a senator alters her behavior in response to a House more conservative with respect to civil rights, or how a House member responds to a more conservative Senate. In result 1 , I prove that the net sophisticated voting function $s(\cdot)$ is increasing in the bliss point of the median member of the other chamber $x_{o}$ (Martin 1998, 308). This proof requires a substantive assumption that the two chambers are close enough in ideological space such that the compromise in conference is less conservative than the status quo. ${ }^{10}$ The first hypothesis follows.

Hypothesis 1. Holding all else constant, as Congress becomes more conservative, the net amount of sophisticated voting behavior in the other chamber will increase.

This hypothesis is illustrated in the top two lines of Figure 1. This figure contains six realizations of the separation of powers game, and it illustrates all three hypotheses using typical examples. Both the Court and the president prefer the policy proposal $\left(x_{o}+A\right) / 2$ to $Q$. Thus, members of Congress between the cutpoint $(A+Q) / 2$ and $\left(x_{o}+A+2 Q\right) / 4$ will vote in a sophisticated manner for $A$ because they prefer the policy outcome to the status quo. As the other chamber becomes more conservative, illustrated in the second line of the figure, the width of the interval increases, which implies an increase in the net amount of sophisticated congressional voting behavior.

The second comparative static concerns the policy preference of the president $x_{e}$, based on my result 2 that net sophisticated voting function $s(\cdot)$ is decreasing in the president's bliss point $x_{e}$ (Martin 1998, 309).

HyPOTHEsIs 2. Holding all else constant, as the president becomes more liberal, the net amount of sophisticated congressional voting behavior will increase.

In Figure 1, the third line represents a conservative presidency. Here, the president vetoes all legislation,

10 This assumption is benign, as no member of Congress would agree to play the game in the pathological situation where $\left(x_{0}+x_{c}\right) / 2>$ $Q$. 


\section{FIGURE 1. Illustrations of Hypotheses for Particular Realizations of the Game}

\section{Hypothesis One}
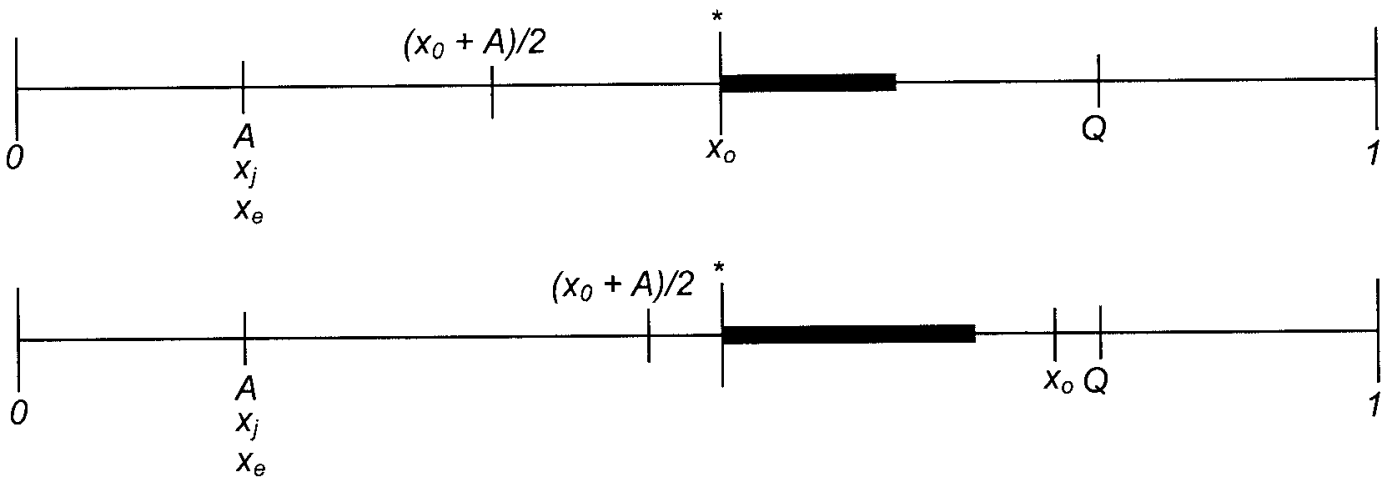

Hypothesis Two
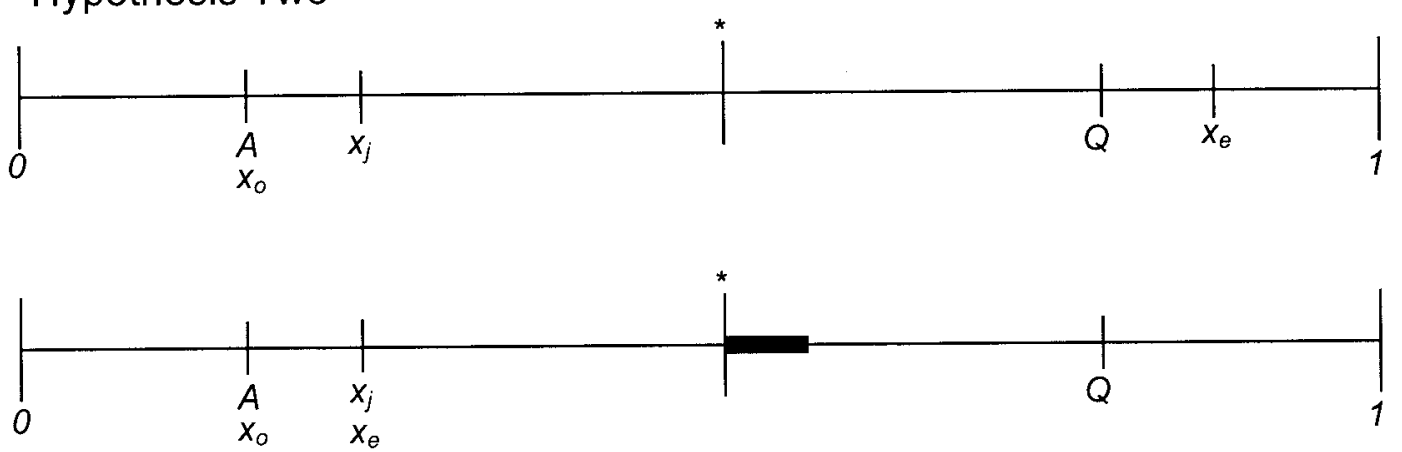

Hypothesis Three
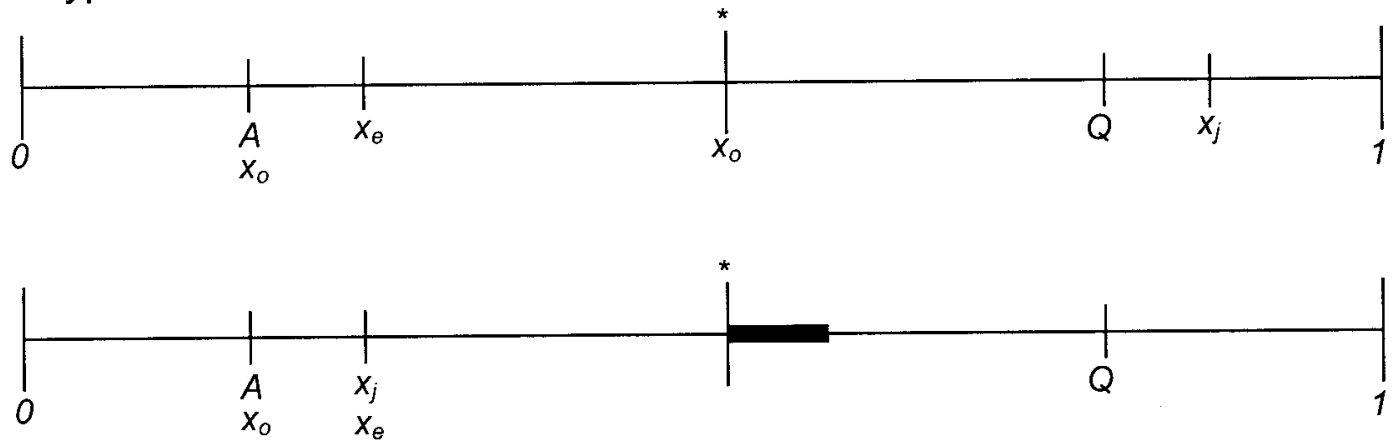

Note: ${ }^{*}=(A+Q) / 2$, and denotes sophisticated congressional behavior. All other quantities are the parameters of the game: the status quo $Q$, the policy alternative $A$, the median member of the other chamber $x_{o}$, the president $x_{e}$, and the median Supreme Court justice $x_{j}$.

so no sophisticated congressional voting behavior is predicted. For a more liberal president, the story changes. In the fourth line of Figure 1, all members of Congress between $(A+Q) / 2$ and $\left(x_{j}+Q\right) / 2$ will behave in a sophisticated manner and vote for $A$ instead of their sincere preference $Q$. This suggests that as the president becomes more liberal, on balance more members of Congress will behave contrary to their sincere preferences.
The final comparative static concerns the policy preference of the median Supreme Court justice $x_{j}$. In result 3 , I prove that the net sophisticated voting function $s(\cdot)$ is decreasing in the bliss point of the median Supreme Court justice $x_{j}$, given a substantive assumption that the Court is either liberal or conservative but not moderate (near the status quo) (Martin 1998, 310). From this result, I state the final hypothesis. 
HypotHEsis 3. Holding all else constant, as the median Supreme Court justice becomes more liberal, the net amount of sophisticated congressional voting behavior will increase.

This hypothesis is illustrated in the final two lines of Figure 1. In the first instance, a conservative Court overturns all legislation, which means that each member of Congress will vote sincerely. When the Court is more liberal ( $x_{j}$ decreases), more members of Congress have the incentive to behave in a sophisticated manner and vote for $A$ (in fact, it will be those members between $(A+Q) / 2$ and $\left.\left(x_{j}+Q\right) / 2\right)$. This interval widens as the Court becomes more liberal, which comports with hypothesis 3 .

\section{RESEARCH DESIGN}

To test the hypotheses, I consider all civil rights roll call votes between 1953 and 1992. This issue area (1) encompasses a substantial amount of legislation, (2) involves considerable litigation, (3) is politically contentious, which produces interinstitutional conflict, and (4) is politically important, especially throughout the last half of the century.

\section{Case Selection}

The substantive focus is all roll call votes on civil rights bills from the $83 \mathrm{~d}$ to the $102 \mathrm{~d}$ Congress. During this period, Congress passed many important pieces of civil rights legislation. Some were signed into law (e.g., the Civil Rights Act of 1964), some failed to pass through the legislature (e.g., the Civil Rights Act of 1966), and some were vetoed by the president (e.g., the Civil Rights Act of 1990). The issue dominated politics in the 1960s and continued to play an important role thereafter.

I am not aware of a highly reliable database of congressional roll calls from which one can sort votes into specific issue areas. Thus, selecting roll call votes that relate to civil rights is not a trivial matter. Clausen (1973) defines civil liberties very broadly, encompassing legislation that ranges from freedom from unsanctioned violence and the right to a fair trial, to the protection of constitutionally guaranteed rights. To avoid the possibility of multidimensionality, I focus on civil rights more narrowly defined. According to Black (1991, 169), civil rights legislation is "intended to implement and give further force to basic personal rights guaranteed by [the] Constitution,.... [which] prohibit discrimination in employment, education, public accommodations, etc. based on race, color, age, or religion." My goal is to select all roll calls that explicitly address the governmental guarantee of the rights provided in the Bill of Rights and subsequent amendments to the Constitution.

I begin by broadly selecting all cases that address race, gender, and sexual preference. Poole and Rosenthal (1997) provide a database of roll call votes (of unknown reliability) that classifies legislation with ninety-nine specific issue codes. From this I selected all legislation coded as women's equality, civil rights/ desegregation/busing/affirmative action, homosexuality, voting rights, and (nonblack) minorities (pp. 2602 ). This selection, however, has a number of limitations. It not only puts implicit and explicit civil rights legislation into one category but also fails to identify some important legislation that affects civil rights (such as education and appropriations legislation). To add to this universe of cases, I turned to another source of roll call votes: the Congressional Quarterly Almanac (CQ 1953-92). I used the index to select all legislation that affects civil rights as defined above. I specifically included all pieces of legislation indexed by the following words: affirmative action, civil rights, desegregation, discrimination, equality, homosexuality, literacy test, minorities, poll tax, voting rights, and women. I combined both sets to form my universe of civil rights roll calls.

Some of these roll calls in the universe of cases explicitly affect civil rights (by outlawing discrimination in housing or employment), but others have only an implicit effect (by removing jurisdiction from federal courts, stripping funds from the Department of Justice, or procedural votes in the House and Senate). To narrow this selection to all legislation with a direct effect, I used the abstracts published with each roll call vote in the Congressional Quarterly Almanac. This procedure identified a set of roll calls related to explicit votes for or against protecting civil rights, without the ambiguity that arises in implicit votes. This data set covers votes on amendments, motions to table an amendment or bill, and final passage of bills and resolutions.

\section{Data and Measurement}

The dependent variable in this analysis is the dichotomous congressional vote for or against the protection of civil rights. I first built a data set of individual votes for each roll call. For the 83d to the 97th House, I used data from Poole and Rosenthal (1989). For the 98th to the $102 \mathrm{~d}$ House and the $83 \mathrm{~d}$ to the $102 \mathrm{~d}$ Senate, I used data from the Inter-university Consortium for Political and Social Research and Congressional Quarterly (1997). After all votes were selected, the data were reshaped and stacked into two data sets: one for the House of Representatives and one for the Senate. ${ }^{11} \mathrm{I}$ coded all liberal votes (providing rights or protection to minority groups) as 0 and all conservative votes (stripping rights or protection to minority groups) as 1 . Thus,

\footnotetext{
${ }^{11}$ In the empirical model I assume that, conditional on knowing a member's preference, roll call votes are independent within decision contexts. Clearly, there are members of Congress who can manipulate the agenda to achieve their preferred outcomes (see Enelow and Koehler 1980; McKelvey 1979), which means that votes may not be independent in a particular Congress. Yet, Austen-Smith (1987) demonstrates that an endogenous agenda will produce sincere observed behavior. This lack of independence will bias any empirical analysis toward the null hypothesis of sincere behavior. As suggested by an anonymous reviewer, I reestimated the House model excluding cases considered under a closed rule. The results are robust given this specification (see Table 3 on the replication website).
} 
in the data set, $A<Q$, which comports with the analytic assumption used to generate the hypotheses. ${ }^{12}$

To explain the variance in this dependent variable I need two sets of independent variables: one that measures policy preferences for members of Congress and one that measures the political context of the decision. In the analysis, I use Nominate Common Space firstdimension scores to measure congressional preferences (Poole and Rosenthal 1997). ${ }^{13}$ These scores are estimated in the same space across chambers and time, and they ranged from approximately -0.6 (liberal) to 0.6 (conservative) during this period. Poole and Rosenthal use an elaborate multidimensional scaling algorithm on all roll call votes to produce these scores. ${ }^{14}$ In contrast to D-Nominate scores, all members of Congress only get one score based on their entire voting record. These scores are also appealing because they lie on a common space across all Congresses and in both chambers. Poole and Rosenthal use these scores to illustrate stability in congressional voting and to explain voting behavior in many different policy domains. ${ }^{15}$

\section{Political Context}

My strategic account predicts that members of Congress behave in profoundly different ways depending upon the context in which they make their decision. The first measure I require to gauge decision context is one of legislative preferences in the other chamber $\left(x_{o}\right) .{ }^{16}$ To comport with the formal model, I use the

12 This coding convention was used to maximize the size of the sample, particularly the number of decision contexts. It is possible, however, that including votes on conservative proposals may bias the empirical results. Please refer to Appendix Table A-1.

13 The second-dimension scores have been shown useful in explaining additional variance in voting patterns in some policy areas, including civil rights in certain (but not all) Congresses. I employ the first dimension because of its continued importance throughout this period (Poole and Rosenthal 1997). To test the robustness of my results, I reestimated all models using only the Nominate Common Space second-dimension scores (appropriately recoded). The substantive conclusions reached are robust given this specification (see tables 1 and 2 on the replication website).

${ }^{14}$ There is an inherent endogeneity problem with this measurement strategy because Nominate scores are calculated from congressional votes. Because they are computed for all members of Congress across time, the effect of these particular civil rights votes may be minimal. An additional criticism is that the scores may come from strategic congressional behavior. Assume that members sometimes vote in a sophisticated manner and that we have a preference measure based on strategic votes with some random error. Within a decision context $k$, a probit model will predict votes equally well as for the case in which only sincere votes enter the measure. Sophisticated behavior is built into the measure, which makes some conservatives look more liberal than they sincerely are, and some liberals more conservative than they sincerely are. This behavioral equivalence suggests that the biases introduced by strategic congressional voting in the preference measure will bias the analysis toward the null of sincere behavior.

${ }^{15}$ Many factors can explain what members of Congress do: constituency concerns, interest group influence, the desire to move up in the party hierarchy, or the desire to become nationally prominent. Each member of Congress is motivated by one or many of these factors. I assume that these factors can be weighted by the member of Congress into a preferred policy position.

${ }^{16}$ Intrachamber strategic voting may bias the analysis toward finding median member of the other chamber measured with the Nominate Common Space first-dimension scores. ${ }^{17}$ The analysis also requires a measure of presidential policy preferences $\left(x_{e}\right)$. One possibility is the Nominate Common Space measure based on presidential position taking (Poole and Rosenthal 1997). In its stead, I use a measure not directly based on behavior and constructed from a survey of historians and presidency scholars (Segal, Timpone, and Howard 2000). I rescale their social liberalism measure into a social conservatism measure that ranges from 0 to $1 .{ }^{18}$ To test hypothesis 3, I require a measure of the median Supreme Court justice $\left(x_{j}\right)$. Here I use another measure not directly based on behavior (Segal and Spaeth 1993). It has been shown highly reliable in the civil rights domain (Epstein and Mershon 1996). I rescaled these scores from 0 to 1 , representing more or less conservatism.

\section{Statistical Models}

My theory dictates that strategic and nonstrategic members of Congress behave quite differently because of the separation of powers. In the nonstrategic account, members of Congress care about position taking and always vote sincerely for their preferred policy alternative. In contrast, strategic members who care about policy outcomes sometimes cast sophisticated votes to pursue their policy goals. The amount of sophisticated voting depends on the other actors in the separation of powers game.

To model liberal and conservative roll call votes statistically, let $y_{i, k}$ represent a dichotomous congressional decision made in decision context $k$. The range of decision contexts is $k=1, \ldots, K$. The total number of roll call votes cast in each decision context also varies, implying $i=1, \ldots, n_{k}$. A nonstrategic explanation of congressional behavior predicts that votes are functions of preferences alone. Thus, decisions made by every member of Congress in every decision context can be pooled. Because decisions are dichotomous, the nonstrategic account can be tested with a standard probit model. Using a latent utility specification, where $z_{i, k}$ represents an unobserved utility function, yields

$$
\begin{gathered}
y_{i, k}=\left\{\begin{array}{lll}
1 & \text { if } & z_{i, k}>0 \\
0 & \text { if } & z_{i, k} \leq 0
\end{array},\right. \\
z_{i, k}=x_{i, k}^{\prime} \beta+\varepsilon_{i, k} \quad \varepsilon_{i, k} \sim N(0,1) .
\end{gathered}
$$

an influence from the other legislative chamber. An anonymous reviewer suggests an alternative specification that includes the median member of the chamber under consideration as a control variable at the second level of the hierarchical model. All results reported below are robust given this specification (see tables 4 and 5 at the replication website).

${ }_{17}$ In the Senate, one could use the cloture member, which Rule XXII stipulated before 1975 was the $2 / 3$ member, the $3 / 5$ member thereafter. Such a measure is highly correlated with the median measure employed in the analysis, and the results do not differ using either measure.

${ }^{18}$ This measure correlates at $0.926(n=8)$ with the inferential Nominate measure. The empirical results are the same for both measures. 
For this formulation, $x_{i, k}^{\prime}$ is a $(1 \times p)$ row vector of covariates, and $\beta$ is a $(p \times 1)$ column vector of parameters ( $p$ denotes the number of explanatory variables). I adopt a Bayesian approach (see Jackman 2000) and estimate the model with the Gibbs sampling algorithm of Albert and Chib (1993), using conjugate noninformative priors. The row vector of covariates $x_{i, k}^{\prime}$ contains two elements: a constant and my measure of the member's preference. Note that for this nonstrategic model, one estimates a single vector of parameters. The estimated $\beta_{2}$ coefficient gauges the strength of the preference/behavior relationship. If it is positive and differs from zero with high probability, then one can conclude that preferences systematically affect congressional behavior.

The theoretical argument offered above suggests behavioral heterogeneity (Western 1998); that is, members of Congress behave in profoundly different ways depending on the context of their decision. Within a particular decision context $k$, the formulation of the model is nearly the same:

$$
\begin{aligned}
& y_{i, k}=\left\{\begin{array}{lll}
1 & \text { if } & z_{i, k}>0 \\
0 & \text { if } & z_{i, k} \leq 0
\end{array},\right. \\
& z_{i, k}=x_{i, k}^{\prime} \beta_{k}+\varepsilon_{i, k} \quad \varepsilon_{i, k} \sim N(0,1) .
\end{aligned}
$$

The only difference is that the preference/behavior relationship $\beta_{k}$ is measured for each decision context. As hypothesized above, the preference/behavior relationship should systematically covary with measures of political context. Indeed, as the net amount of sophisticated congressional voting behavior increases, $\beta_{k, 2}$ should decrease, and vice versa.

To test these hypotheses, it is necessary to model the changes in the preference/behavior relationship across decision contexts. This can be done with a seemingly unrelated regression (SUR) model. Recall that $\beta_{k}$ is a $(p \times 1)$ column vector of parameters. Thus:

$$
\beta_{k}=W_{k} \alpha+v_{k}, \quad v_{k} \sim N_{p}(0, \Omega) .
$$

$W_{k}$ is a $(p \times q)$ matrix of covariates, $\alpha$ is a $(q \times 1)$ vector of parameters, and $\Omega$ is a $(p \times p)$ variancecovariance matrix. Note that this formulation is hierarchical: The first level relates preferences to decisions, and the second level incorporates context by explaining variation in the $\beta_{k}$ parameters. Since the strategic explanation indicates that the net amount of sophisticated congressional voting behavior should covary with three measures of context defined by the separation of powers, for the strategic probit models I present below, the measure of political context is:

$$
W_{k}=\left[\begin{array}{ccccc}
1 & 0 & 0 & 0 & 0 \\
0 & 1 & x_{o} & x_{e} & x_{j}
\end{array}\right]
$$

The second-level parameters $\alpha$ are used to explain the variance in the preference/behavior relationship across decision contexts. If, for example, that relationship is constant across contexts (formally, $\beta_{k}=c$ for all $k$ ), then the $\alpha$ coefficients for the other chamber, the president, and the judiciary will be zero. If, as predicted in hypothesis 2, the preference/behavior relationship strengthens as a function of presidential conservatism, then the $\alpha$ coefficient on the presidency measure will be positive. Thus, if an element of the $\alpha$ vector is positive, it means that sophisticated behavior is decreasing in that covariate, and vice versa. For example, hypothesis 1 predicts that the net amount of sophisticated congressional voting behavior will increase as the other chamber $\left(x_{o}\right)$ becomes more conservative. Thus, the $\alpha$ coefficient on the other chamber should be negative.

If we knew with certainty the contextual effects (i.e., $v_{k}=0$ for all $k$ ), then we could directly substitute equation 2 into equation 1 and would produce a standard probit model with a handful of interaction terms. After this substitution, our explanatory variables would be a constant, the preference measure, and the preference measure interacted with each of the contextual variables: $x_{o}, x_{e}$, and $x_{j}$ (which vary across decision contexts). We could estimate a vector of $\alpha$ coefficients. In the tables of results that follow, I call this the interaction probit model, which can be estimated using standard techniques. Note that for this model we do not directly estimate each $\beta_{k}$ in each context. In practice, however, it is unlikely that one can model these contextual effects with certainty. To relax this assumption, I employ Markov chain Monte Carlo (MCMC) estimation methods to estimate simultaneously the first-level parameter vectors $\beta_{k}$ and the hyperparameters $\alpha$ and $\Omega$. I refer to this as the hierarchical probit model. As it turns out, the latter outperforms the interaction probit model in all cases and gives a more reliable picture of the effect of the separation of powers on congressional voting. For a detailed discussion of estimation issues, please refer to the Appendix.

\section{Testing the Hypotheses}

To compare the strategic and nonstrategic explanations, I proceed as follows. First, I estimate a nonstrategic model of congressional decision making using the standard probit model. Then, to test hypotheses $1-3$, I estimate an interaction probit model and a hierarchical probit model..$^{19}$ For both these models, the $\alpha$ parameters explain changes in the preference/behavior relationship and can be interpreted just like SUR coefficients. To conserve space, for the hierarchical model I summarize the posterior densities of the preference/ behavior relationship $\beta_{k, 2}$ for each decision context using boxplots, and I only report the $\alpha$ parameters and the variance-covariance matrix $\Omega$. Finally, for all models, I report the log-marginal likelihood, which is useful for model comparison using Bayes factors (Kass and Raftery 1995).

As noted earlier, the $\alpha$ hyperparameters explain heterogeneity in congressional voting behavior. Thus, the $\alpha$ coefficients on the legislative, presidential, and

\footnotetext{
19 To check robustness of the results, I reestimated all models with various informative prior specifications, and the results remain robust (see tables 6 and 7 on the replication website as examples). I also performed posterior sample analysis to assure convergence of the samples.
} 


\section{FIGURE 2. House Pooled Data, Local Regression Line}

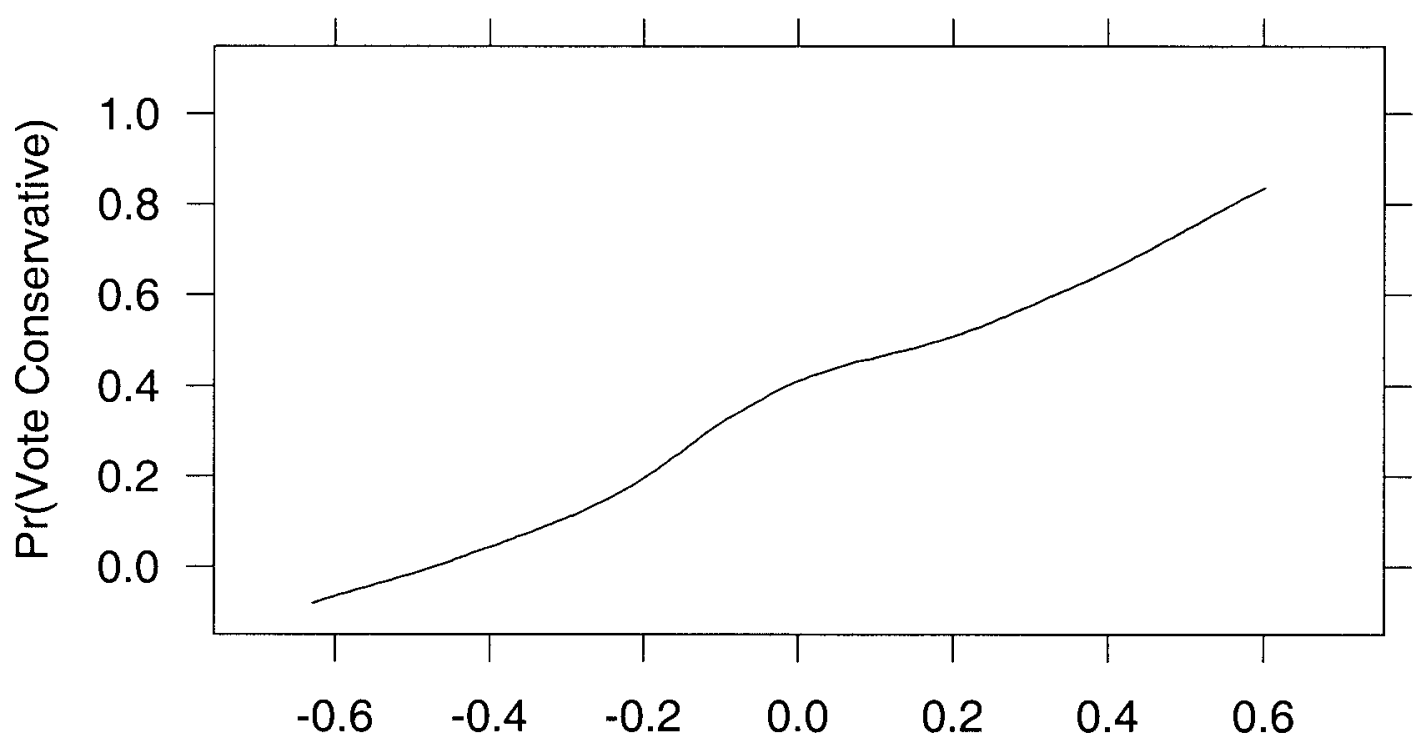

Preferences (Nominate Dimension One)

Note: The points are suppressed in the figure because the vote variable is dichotomous.

judiciary measures tell us how the other institutions affect the preference/behavior relationship for members of Congress and serve as the test of hypotheses 1-3. Hypothesis 1 indicates that, as the other chamber becomes more conservative, more sophisticated voting behavior is to be expected. This implies that the strength of the preference/behavior relationship decreases as the other chamber becomes more conservative. Thus, the $\alpha$-Congress measure should be negative. Hypotheses 2 and 3 indicate that as the president or the median Supreme Court justice become more liberal, more sophisticated voting behavior should be observed. This implies that $\beta_{k}$ increases as $x_{e}$ and $x_{j}$ increase. Thus, we expect the $\alpha$-president and the $\alpha$-Supreme Court coefficients to be positive. If these expectations are borne out, then one can reject the null that members of Congress do not respond strategically to the separation of powers and are solely motivated by position taking. As an additional comparison of the strategic and nonstrategic models, I also compute the Bayes factor between them.

\section{THE HOUSE OF REPRESENTATIVES}

I first examine decision making in the House of Representatives, where votes were cast on many pieces of civil rights legislation from the 84th to the $102 \mathrm{~d}$ Congress (no votes were cast in the $83 \mathrm{~d}$ ). These votes were cast in $K=34$ decision contexts.

The first result I present is from a nonstrategic account of congressional decision making. I pool all data across all decision contexts from 1953 to 1992 and investigate the relationship between preferences and behavior. Figure 2 contains a local regression line that relates House pref- erences to votes. Because the vote variable is dichotomous, I suppress the data points in the graph. The line shows the probability of casting a conservative vote for a given preference. As expected, House preferences are directly related to the vote; as members become more conservative, they vote more often for conservative civil rights policy. This is far from an astonishing finding, but it serves as a baseline for comparison.

In the first column of Table 1, I summarize the posterior density from the probit model. Note that one can interpret the posterior mean or median just as one would interpret a point estimate in classical models, and the posterior standard deviation as the standard error. These results demonstrate that preferences are strongly related to the vote. Indeed, $100 \%$ of the posterior density sample for $\beta_{2}$ is positive. The posterior sample has a minute standard deviation.

Before I present statistical results from the strategic House model, I investigate how the preference/behavior relationship changes in different decision contexts using a graphical device called the conditioning plot. A conditioning plot is similar to the scatterplot in Figure 2, but the data are conditioned by a third variable. For these graphs, I divide the data based on the 25th, 50th, and 75th percentiles of the conditioning variable. Thus, in Figure 3, the bottom cell contains the data from the minimum to the 25th percentile of the Senate median measure, the next cell up contains data from the 25th to the 50th percentile of the Senate median measure, and so forth. By my strategic account, the slopes of the local regression lines should vary as the measures of decision context change. With these plots, one can easily see how the relationship changes as a function of another variable.

The coplot in Figure 3 contains the preference/ 
TABLE 1. Posterior Density Summaries for House Models

\begin{tabular}{|c|c|c|c|c|c|c|c|c|c|}
\hline \multirow[b]{2}{*}{ Variable } & \multicolumn{3}{|c|}{ Pooled Probit Model } & \multicolumn{3}{|c|}{ Interaction Probit Model } & \multicolumn{3}{|c|}{ Hierarchical Probit Model } \\
\hline & $\begin{array}{l}\text { Post } \\
\text { Mean }\end{array}$ & $\begin{array}{c}\text { Post } \\
\text { Median }\end{array}$ & $\begin{array}{l}\text { Post } \\
\text { StD }\end{array}$ & $\begin{array}{l}\text { Post } \\
\text { Mean }\end{array}$ & $\begin{array}{c}\text { Post } \\
\text { Median }\end{array}$ & $\begin{array}{l}\text { Post } \\
\text { StD }\end{array}$ & $\begin{array}{l}\text { Post } \\
\text { Mean }\end{array}$ & $\begin{array}{c}\text { Post } \\
\text { Median }\end{array}$ & $\begin{array}{c}\text { Post } \\
\text { StD }\end{array}$ \\
\hline$\beta_{1}-$ Constant & -0.405 & -0.405 & 0.008 & & & & & & \\
\hline$\beta_{2}-$ Preference & 2.309 & 2.309 & 0.032 & & & & & & \\
\hline$\alpha_{1}-$ Constant & & & & -0.405 & -0.405 & 0.008 & -0.589 & -0.590 & 0.253 \\
\hline$\alpha_{2}-$ Preference constant & & & & 0.071 & 0.071 & 0.122 & 0.665 & 0.656 & 0.351 \\
\hline$\alpha_{3}-$ Preference $\times$ Senate & & & & -5.435 & -5.428 & 0.472 & -2.056 & -2.044 & 0.935 \\
\hline$\alpha_{4}-$ Preference $\times$ president & & & & -0.379 & -0.380 & 0.210 & 0.666 & 0.655 & 0.562 \\
\hline$\alpha_{5}-$ Preference $\times$ judiciary & & & & 4.624 & 4.626 & 0.193 & 4.081 & 4.096 & 0.577 \\
\hline$\Omega_{11}-$ Error & & & & & & & 0.481 & 0.452 & 0.156 \\
\hline$\Omega_{12}-$ Error & & & & & & & -0.008 & -0.010 & 0.187 \\
\hline$\Omega_{22}-$ Error & & & & & & & 2.187 & 2.101 & 0.574 \\
\hline Ln(marginal likelihood) & $-17,041.62$ & & & $-16,524.91$ & & & $-14,675.55$ & & \\
\hline Burn-in iterations & 500 & & & 500 & & & 500 & & \\
\hline Gibbs iterations & 5,000 & & & 5,000 & & & 5,000 & & \\
\hline Contexts & 34 & & & 34 & & & 34 & & \\
\hline$n$ & 31,429 & & & 31,429 & & & 31,429 & & \\
\hline
\end{tabular}

behavior relationship conditioned on the Senate median. Hypothesis 1 predicts that as the Senate gets more conservative, we expect more sophisticated behavior. The bottom three cells of the coplot show a strong relationship that resembles the pattern in Figure 2 (with a slight deviation in the moderate liberal cell). As the Senate median grows more conservative, the relationship lessens not only in level but also in curvature, which is apparent in the top cell. The nonstrategic baseline suggests that the probability of voting conservatively is strictly increasing in preferences. The pronounced bump in the top cell is suggestive of the behavior predicted in hypothesis 1 .

Hypothesis 2 predicts that as the president becomes more conservative, the slope of the local regression line should increase. In the bottom cell of Figure 4 we see the relationship between preference and behavior during the Johnson years. Compare this with the top cell, when Richard Nixon and Ronald Reagan were in the White House. We see a strengthening relationship when the president is more conservative, which implies more sincere voting behavior. Again, we see departures from sincere behavior at the middle of the policy space in the bottom cell. For this bivariate analysis, this finding comports with hypothesis 2 .

In Figure 5, I condition House behavior on the median Supreme Court justice. Again, the expectations are borne out. Indeed, in both of the lower cells we observe many moderate House members voting for conservative policy, which is consistent with a desire to prevent extreme liberal outcomes. This is why there are bumps around the middle of each graph. As the judiciary grows more conservative, we see a much stronger relationship. Indeed, during the early Burger
Court in the second cell, and the late Burger and Rehnquist Courts in the top cell, we see a much stronger preference/behavior relationship, which is consistent with hypothesis 3 .

The exploratory data analysis just presented is persuasive on its face, the next step is to see whether the hypothesized relationships hold in a multivariate setting. The statistical results are given in the final two columns of Table 1. For the two strategic models, it is important to determine whether the simpler interaction model suffices or whether the hierarchical model is necessary. To make this determination, I rely on a model comparison tool called the Bayes factor. With an equal prior probability that each model is the true data-generating mechanism, the Bayes factor is simply the ratio of marginal likelihoods (or the difference between the log-marginal likelihood). The Bayes factor $B_{j, k}$ can be interpreted on the scale of probability that model $j$ is the true data-generating mechanism compared to model $k$. If the Bayes factor is greater than five, it is very strong evidence that $j$ is the better model (Kass and Raftery 1995, 777).

The Bayes factor between the hierarchical probit model and the interactive probit model is $B_{j, k}=$ 1849.36 , which suggests that the hierarchical model is superior. In addition, the statistically significant estimates of the error parameters suggest that the simplifying assumption needed to employ the interaction model does not hold. As we would expect, the interaction model has larger posterior means and smaller standard deviations than the hierarchical model, which overstate the confidence we have in the results. Although the interaction model serves to illustrate the modeling strategy for the strategic case, I will rely on 


\section{FIGURE 3. House Local Regression Conditioned on Senate Median}

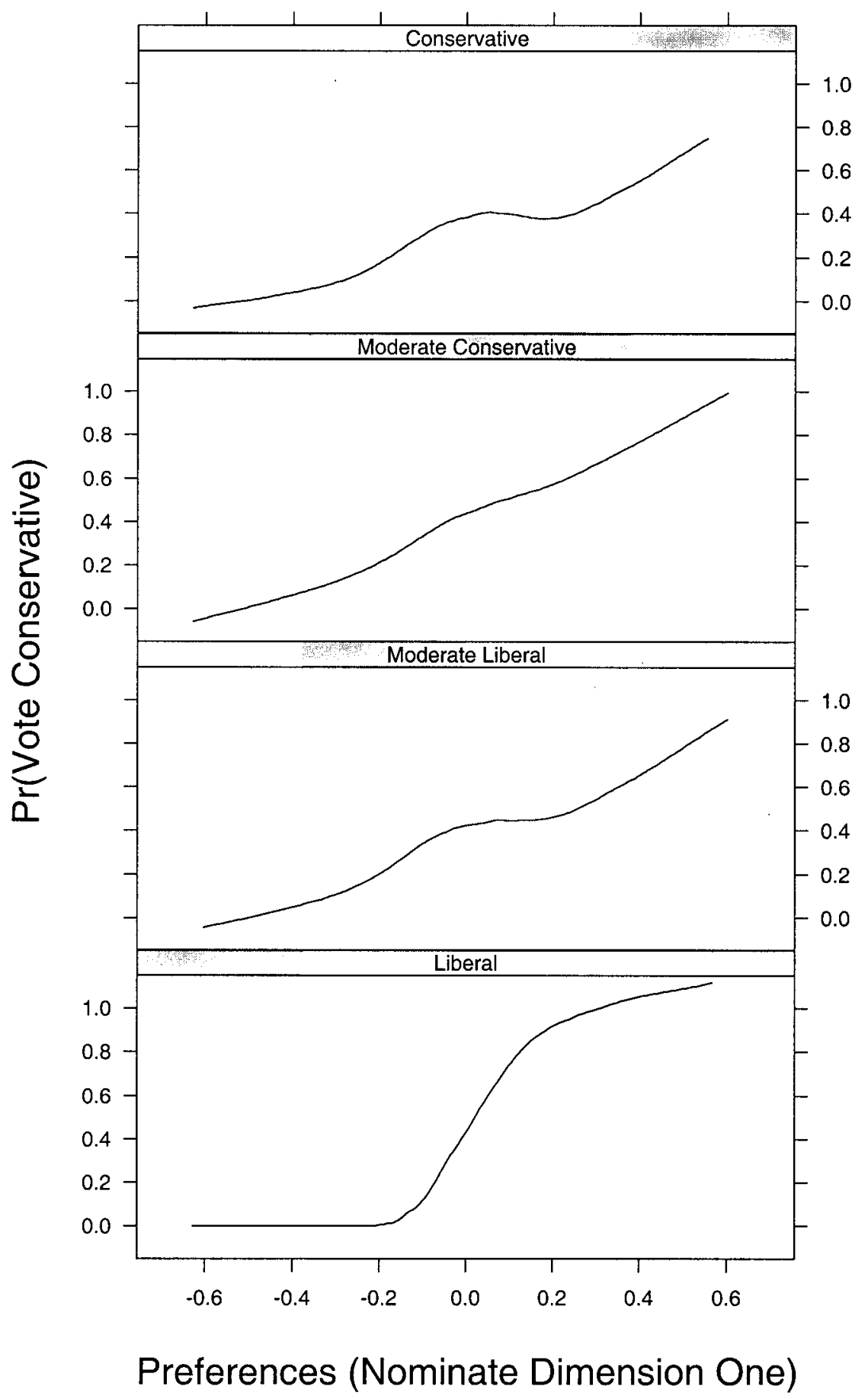

Note: The 25th, 50th, and 75th percentiles for the Senate median are $-0.17,-0.12$, and -0.08 , respectively.

the superior hierarchical model for inference. As hypothesized, the posterior mean of $\alpha$-Senate is negative $(-2.06)$, with a standard deviation of 0.93 . Because $98.4 \%$ of the posterior density sample is less than zero, there is a $98.4 \%$ probability that $\alpha$-Senate is negative. This demonstrates that the Senate significantly and systematically constrains House behavior, as predicted in hypothesis 1 .

The results for the presidency are not as compelling.
Although the posterior mean is above zero, the posterior standard deviation is large, and only $88.9 \%$ of the posterior density is positive. This means that there is an $88.9 \%$ chance that this coefficient is positive, which many would not regard as a significant result. Thus, the conclusion drawn from Figure 4 is incorrect; in the multivariate analysis, the effect of the presidency is insignificant. The $\alpha$-judiciary coefficient, however, is much stronger. The posterior mean for the judicial coefficient is large (4.08), 


\section{FIGURE 4. House Local Regression Conditioned on Presidential Social Conservatism}

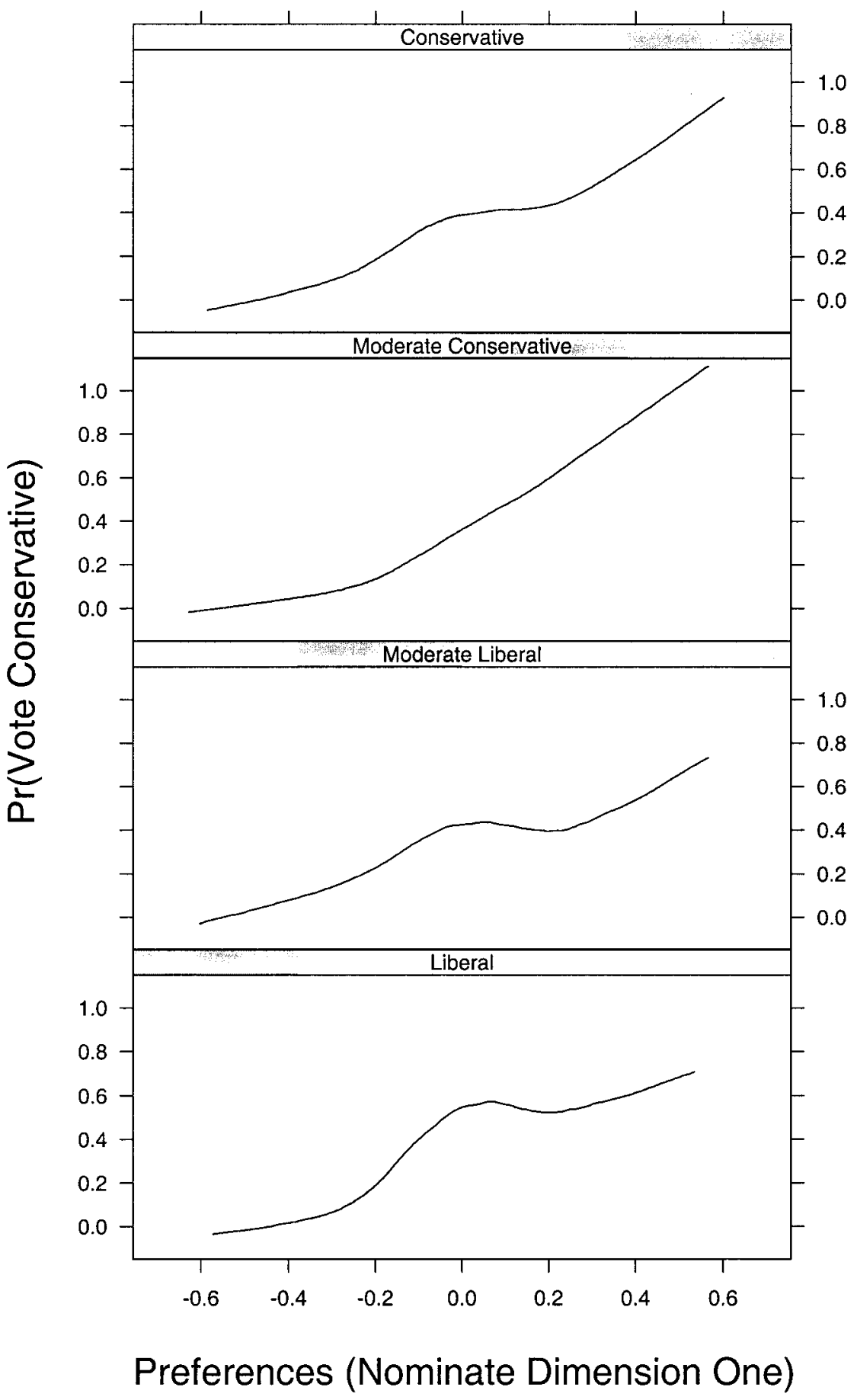

Note: The 25th, 50th, and 75th percentiles for presidential social conservatism are $0.33,0.55$, and 0.66 , respectively

with a small standard deviation (0.58). Indeed, $100 \%$ of the posterior density sample is positive. This demonstrates that the Supreme Court constrains House behavior in the direction hypothesized in hypothesis 3.

In Figure 6 I plot posterior density boxplots for the $\beta_{k, 2}$ coefficients that measure the strength of the preference/behavior relationship. For each decision context, these boxplots summarize the posterior density. For the purposes of comparison, I include the boxplot for the pooled probit model on the far right of the figure. This is the level we would expect all the other boxplots to share if a nonstrategic account were appropriate. If members of Congress are nonstrategic, then each of these posterior density boxplots should share a common mean. As one compares the $\beta_{k, 2}$ coefficients across contexts, there is clear evidence of variance in the preference/behavior relationship. Finally, to compare the strategic and nonstrategic ac- 


\section{FIGURE 5. House Local Regression Conditioned on Judicial Conservatism}

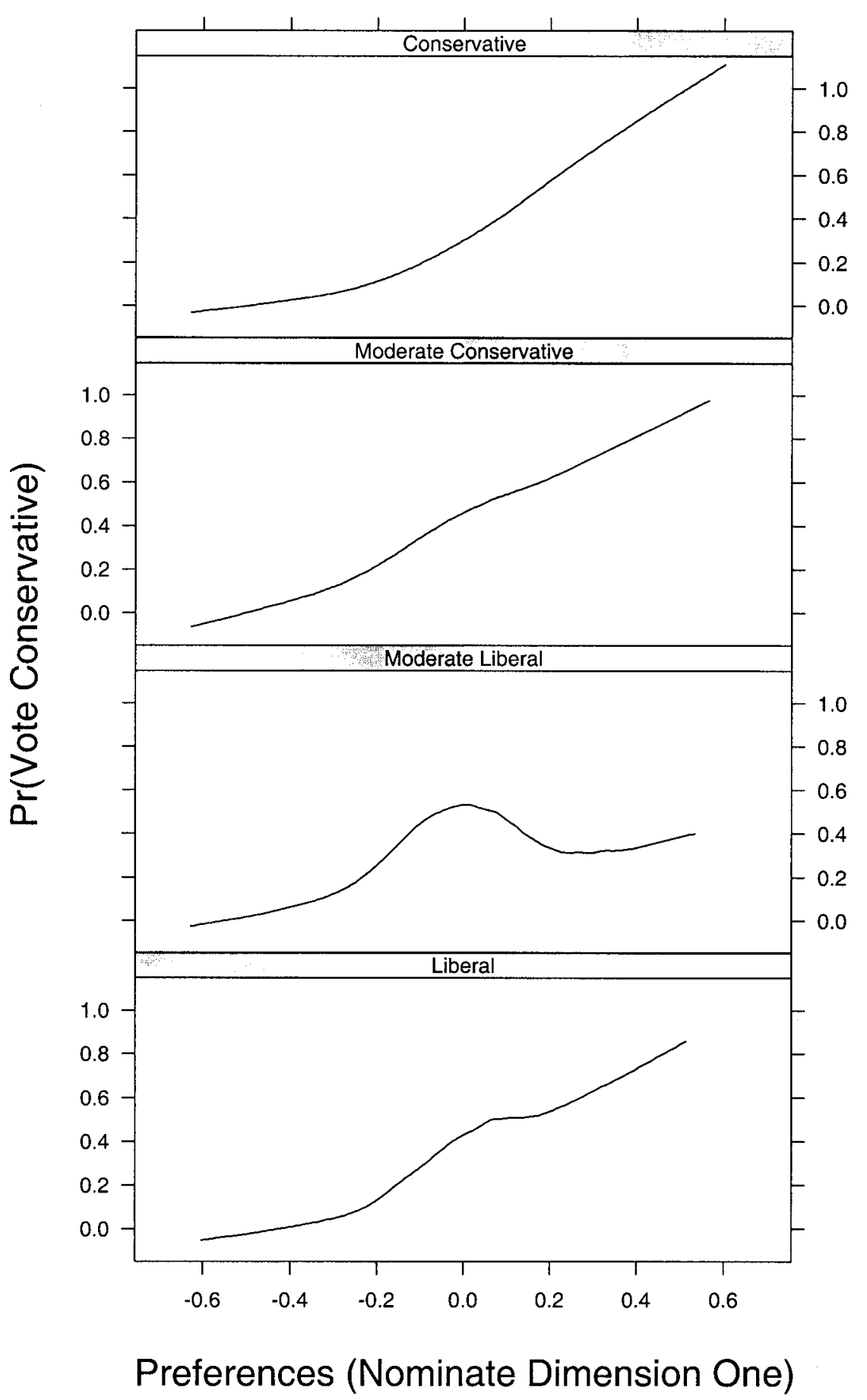

Note: The 25th, 50th, and 75th percentiles for judicial conservatism are $0.25,0.28$, and 0.63 , respectively.

counts, I compute the Bayes factor between the hierarchical probit model and the pooled probit model, $B_{j, k}=2366.07$, which is much greater than five. This is additional evidence that the hierarchical probit model fits the data better than the pooled probit model, which implies that my strategic account of House behavior not only comports with the hypotheses but also is a stronger statistical model than the non- strategic one. For the House, I can confidently reject the null of nonstrategic congressional voting behavior.

\section{THE SENATE}

The House results are quite strong, but the question remains whether the same relationships hold in the Senate. The institutional differences between the 


\section{FIGURE 6. Posterior Density Summaries for the House Preference Measure, by Decision Context}

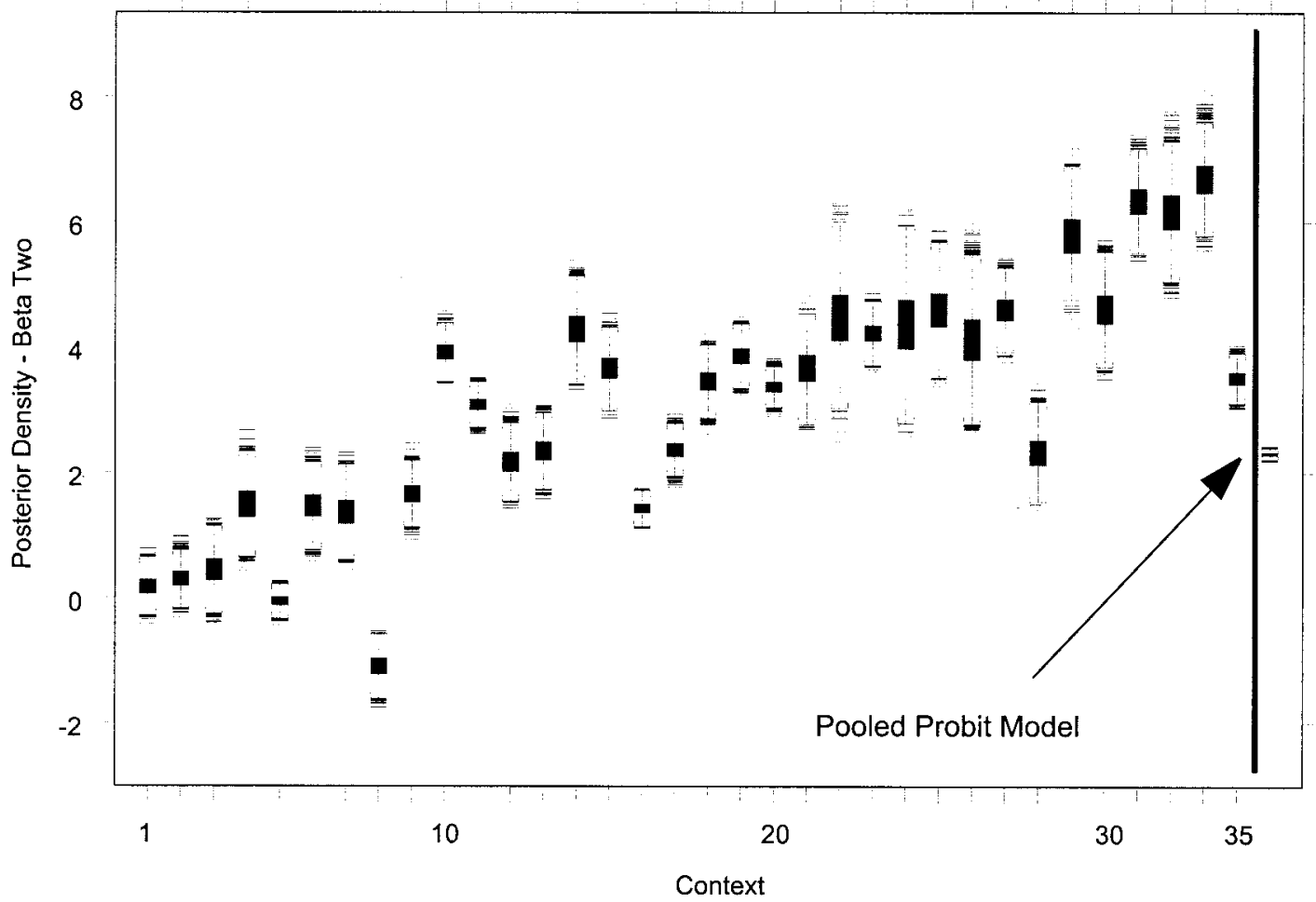

Note: The posterior density summaries are for the House hierarchical probit model. For each context, the central $50 \%$ of the distribution is summarized by the box, and the central $95 \%$ of the distribution by the upper and lower brackets. Outlying values outside the central $95 \%$ of the density are denoted by horizontal lines.

chambers might lead to a different reaction to the separation of powers. The theory, however, indicates that both should respond similarly.

The exploratory data analysis for the Senate is reminiscent of that for the House, so I only report results from the statistical analysis. I summarize the posterior density for the pooled probit model in the first column of Table 2. Just as with the House data, the posterior mean is positive (1.42), and the posterior standard deviation is small (.04). I report estimates for the interaction probit model and the hierarchical probit model in the last two columns of Table 2. Again, the Bayes factor between the two strategic models is greater than five $\left(B_{j, k}=960.33\right)$. This, along with the statistically significant estimates of the error parameters, suggests that the hierarchical model is appropriate. In this case, relying on the interaction model would yield incorrect conclusions about the importance of the presidency. I again rely on the results from the hierarchical model for interpretation. These Senate results bear strong similarity to the House results. Hypothesis 1 is supported in this model. The posterior mean of $\alpha$-House is -1.44 , with a posterior standard deviation of 0.97 . This is somewhat large, but $92.6 \%$ of the posterior density sample lies below zero, which is marginally significant support for the first hypothesis. Just as with the House, the presidency coefficient does not achieve significance in this multivariate setting. The $\alpha$ coefficient on the Supreme Court measure, however, is strongly significant and positive (3.55), with a small standard deviation (.71). This demonstrates that the Supreme Court significantly constrains the actions of senators, as predicted in hypothesis 3 .

To compare further the strategic and nonstrategic models, I construct in Figure 7 posterior density boxplots for the coefficients that measure the preference/ behavior relationship in the Senate. Just as with the House data, it is clear that they are not constant across decision contexts. Decision contexts 8 and 9 provide a striking comparison. From one context to the next, there was turnover in the White House (Lyndon Johnson, the most liberal president of the period, took office), and another liberal justice was added to the Supreme Court (Byron White). When one compares the boxplots from the strategic model to the single boxplot from the nonstrategic (probit) model on the far right-hand side, it is clear that senators behave differently in various decision contexts. Not only the means vary, but also the variance of the distributions. The final piece of evidence on the Senate side is the Bayes factor between the two models. Here $B_{j, k}=$ 1091.10, which implies that for the Senate data the hierarchical probit model replicates the data-generating mechanism far better than the probit model. Senators, too, strategically respond to the separation of powers. 


\section{TABLE 2. Posterior Density Summaries for Senate Models}

\begin{tabular}{|c|c|c|c|c|c|c|c|c|c|}
\hline \multirow[b]{2}{*}{ Variable } & \multicolumn{3}{|c|}{ Pooled Probit Model } & \multicolumn{3}{|c|}{ Interaction Probit Model } & \multicolumn{3}{|c|}{ Hierarchical Probit Model } \\
\hline & $\begin{array}{l}\text { Post } \\
\text { Mean }\end{array}$ & $\begin{array}{c}\text { Post } \\
\text { Median }\end{array}$ & $\begin{array}{l}\text { Post } \\
\text { StD }\end{array}$ & $\begin{array}{l}\text { Post } \\
\text { Mean }\end{array}$ & $\begin{array}{c}\text { Post } \\
\text { Median }\end{array}$ & $\begin{array}{l}\text { Post } \\
\text { StD }\end{array}$ & $\begin{array}{l}\text { Post } \\
\text { Mean }\end{array}$ & $\begin{array}{c}\text { Post } \\
\text { Median }\end{array}$ & $\begin{array}{l}\text { Post } \\
\text { StD }\end{array}$ \\
\hline$\beta_{1}-$ Constant & -0.297 & -0.297 & 0.012 & & & & & & \\
\hline$\beta_{2}-$ Preference & 1.424 & 1.425 & 0.038 & & & & & & \\
\hline$\alpha_{1}-$ Constant & & & & -0.302 & -0.302 & 0.012 & -0.552 & -0.556 & 0.212 \\
\hline$\alpha_{2}-$ Preference constant & & & & 0.483 & 0.483 & 0.093 & 0.431 & 0.423 & 0.399 \\
\hline$\alpha_{3}-$ Preference $\times$ Senate & & & & -3.185 & -3.181 & 0.738 & -1.441 & -1.432 & 0.975 \\
\hline$\alpha_{4}-$ Preference $\times$ president & & & & -0.708 & -0.709 & 0.215 & 0.452 & 0.453 & 0.657 \\
\hline$\alpha_{5}-$ Preference $\times$ judiciary & & & & 3.487 & 3.488 & 0.281 & 3.551 & 3.547 & 0.706 \\
\hline$\Omega_{11}-$ Error & & & & & & & 0.835 & 0.796 & 0.247 \\
\hline$\Omega_{12}-$ Error & & & & & & & 0.052 & 0.051 & 0.239 \\
\hline$\Omega_{22}-$ Error & & & & & & & 1.542 & 1.464 & 0.466 \\
\hline Ln(marginal likelihood) & $-7,243.48$ & & & $-7,112.71$ & & & $-6,152.38$ & & \\
\hline Burn-in iterations & 500 & & & 500 & & & 500 & & \\
\hline Gibbs iterations & 5,000 & & & 5,000 & & & 5,000 & & \\
\hline Contexts & 30 & & & 30 & & & 30 & & \\
\hline$n$ & 12,198 & & & 12,198 & & & 12,198 & & \\
\hline
\end{tabular}

FIGURE 7. Posterior Density Summaries for the Senate Preference Measure, by Decision Context

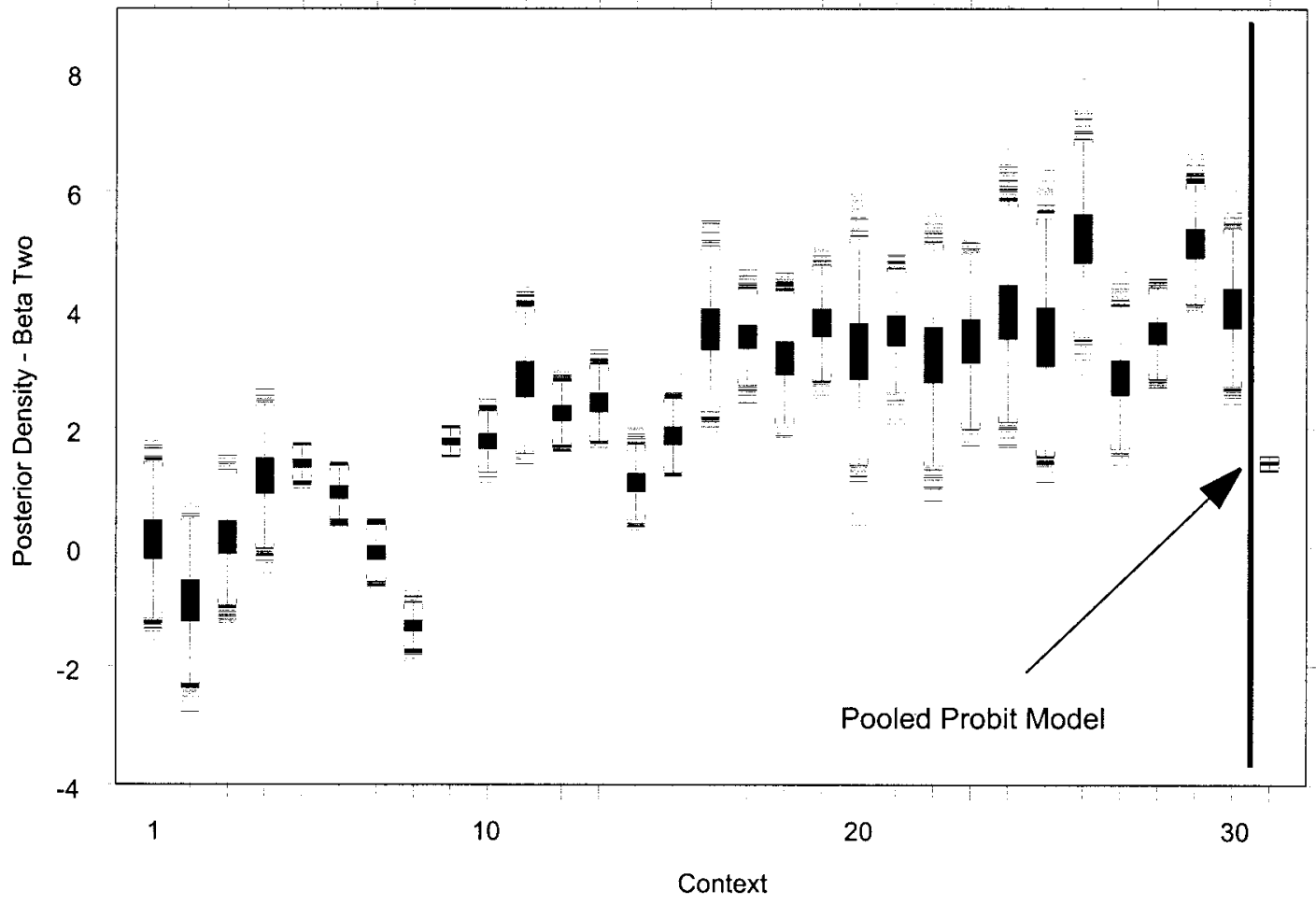

Note: The posterior density summaries are for the Senate hierarchical probit model. For each context, the central $50 \%$ of the distribution is summarized by the box, and the central $95 \%$ of the distribution by the upper and lower brackets. Outlying values outside the central $95 \%$ of the density are denoted by horizontal lines. 


\section{CONCLUSION}

I began with two questions: Does the separation of powers influence congressional decision makers? Are members of Congress motivated by credit-claiming concerns when they cast roll call votes? The results of my analysis demonstrate that the separation of powers constrains the decisions that members of Congress make, and tangible policy outcomes are thus important to achieving congressional goals. The evidence suggests that some members of Congress use their roll call votes to claim credit for policies obtained in the separation of powers system.

One interesting finding, in both the House and Senate, is that the president does not seem to constrain congressional behavior. Why? It is clear that congressional agenda setters take the president into account when making proposals on the floor (Mouw and MacKuen 1992). In addition, the White House is quite involved with congressional leaders and committee staff when legislation is being crafted. Thus, the presidential effect on congressional behavior may occur earlier in the policy process, which would explain why no constraint was manifest in the data.

The major finding of this research is that members of Congress take into account the separation of powers when casting roll call votes. The evidence allows me to reject the null that members of Congress exclusively take positions when casting roll call votes. These findings are consistent with both position taking and credit claiming. Some members use the roll call to set their policy declarations in stone (by always casting sincere votes), and some pursue policy outcomes in the separation of powers system (by voting strategically, which sometimes may be observably sophisticated). The question remains as to when concerns about separation of powers are paramount, which I leave for future research.

Denzau, Riker, and Shepsle (1985) argue that it is very difficult for incumbents to justify sophisticated roll call votes to their constituents. Even so, these findings demonstrate strategic behavior that can manifest itself in sophisticated voting. Indeed, for a multitude of reasons, members of Congress are concerned about not only casting the right vote but also obtaining the best policy outcome. These results are also important when viewed in terms of the policy dimension theory and the ideological model, both of which assert that members of Congress always vote sincerely. When we recognize that policy is the result of interactions among the three branches of government, it becomes clear that the assumption of sincere congressional behavior is suspect and, as the results demonstrate, inappropriate. When we construct explanations of behavior and voting in Congress, it is important to model explicitlytheoretically and empirically-the institutional rules that structure the interactions.

\section{APPENDIX: ESTIMATION AND SUPPLEMENTARY RESULTS}

My hierarchical probit model is similar to other models used successfully in political science research. Western (1998) makes a compelling case for hierarchical models when there is "behavioral heterogeneity." He argues that they are particularly useful in the study of comparative politics, when causal complexity makes traditional models inappropriate. This is similar to the idea of fractional pooling (Bartels 1996). Bayesian hierarchical models are the common ground between the extreme of pooling data across contexts or estimating models for each context, and they allow for inference about individual behavior as well as the causes of heterogeneity across contexts. The hierarchical model employed here is a nonlinear variant of the "general multilevel model" (see Jones and Steenberger 1997 for an introduction). Because the model is hierarchical, estimation is not straightforward. One could substitute equation 2 into equation 1, which would yield

$$
\begin{gathered}
z_{i, k}=x_{i, k}^{\prime} W_{k} \alpha+x_{i, k}^{\prime} \nu_{k}+\varepsilon_{i, k} \\
\nu_{k} \sim N_{p}(0, \Omega) \quad \varepsilon_{i, k} \sim N(0,1) .
\end{gathered}
$$

This is equivalent to a latent utility specification for a probit model with fixed and random effects. As noted in the text, if we could assume that $v_{k}=0$ for all $k$, this would reduce to a probit model with many interactive terms. ${ }^{20}$

From a frequentist perspective, estimation of this model is quite difficult. For a continuous response variable (a simpler case), Jones and Steenbergen (1997) demonstrate the need to use generalized least squares (GLS) to estimate the first-level parameters, maximum likelihood estimation (MLE) to estimate the variance components, and empirical Bayes methods to estimate the second-level parameters. These problems are compounded when one moves to a dichotomous response variable. First, there are problems when estimating fixed effects with a small number of contexts (Greene 1997). In addition, Rodríguez and Goldman (1995) assess frequentist estimation techniques for multilevel models with binary outcomes (the case here). Given a set of Monte Carlo experiments, as well as the analysis of health care use in Guatemala, they demonstrate that the random effects in binary response models cannot be estimated with "acceptable levels of bias and precision" when the number of contexts is modest (p. 87). The alternative they suggest for these models is to adopt a Bayesian estimation strategy and estimate the model using the Gibbs sampling algorithm (p. 87). This is consistent with the theoretical result that hierarchical Bayes dominates fully pooled and completely separated models on a mean square error (MSE) basis (Efron and Morris 1973).

By including prior probability distributions for the hyperparameters $\alpha$ and $\Omega$, one can use the Gibbs sampling algorithm to simulate directly from the posterior distribution $f\left(\left\{\beta_{k}\right\} \alpha, \Omega \mid y\right)$. In the analysis presented above, I assume Normal independent priors with mean zero and variance of 100 for the $\beta$ parameters in the pooled probit model and the $\alpha$ parameters in the interaction and hierarchical probit models. For the variance parameters $\Omega$, I employ a Wishart prior with large variance. As demonstrated in tables 6 and 7

\footnotetext{
20 The independence assumptions for the hierarchical model derive from one fundamental notion: Given a realization of the separation of powers game and a bliss point, all members of Congress behave identically. In other words, all the relevant information about congressional behavior is included in the model. This implies independence within clusters $\left(\varepsilon_{i, k}\right.$ i.i.d. Normal), conditional on the hyperparameters $\alpha$ and $\Omega$. At the second level of the hierarchy, the assumption is that, knowing the parameters of the separation of powers game, all members of Congress behave the same, and thus their behavior can be modeled as drawn from a common distribution ( $\beta_{k}$ i.i.d. multivariate Normal). The assumption that the errors at the first level of the hierarchy and the second level of the hierarchy are independent is a necessary modeling assumption.
} 
TABLE A-1. Posterior Density Summaries for House and Senate Hierarchical Probit Models $(A<Q)$

\begin{tabular}{|c|c|c|c|c|c|c|}
\hline \multirow[b]{2}{*}{ Variable } & \multicolumn{3}{|c|}{ House Hierarchical Probit Model } & \multicolumn{3}{|c|}{ Senate Hierarchical Probit Model } \\
\hline & Post Mean & Post Median & Post StD & Post Mean & Post Median & Post StD \\
\hline$\alpha_{1}-$ Constant & -0.711 & -0.711 & 0.279 & -0.845 & -0.850 & 0.237 \\
\hline$\alpha_{2}-$ Preference constant & 0.402 & 0.401 & 0.378 & 0.629 & 0.629 & 0.435 \\
\hline$\alpha_{3}-$ Preference $\times$ Senate & -1.872 & -1.846 & 0.961 & -1.431 & -1.438 & 1.013 \\
\hline$\alpha_{4}-$ Preference $\times$ president & 0.445 & 0.429 & 0.597 & 0.066 & 0.048 & 0.701 \\
\hline$\alpha_{5}-$ Preference $\times$ judiciary & 4.797 & 4.806 & 0.663 & 3.641 & 3.642 & 0.732 \\
\hline$\Omega_{11}-$ Error & 0.453 & 0.419 & 0.176 & 0.777 & 0.721 & 0.263 \\
\hline$\Omega_{12}-$ Error & -0.122 & -0.110 & 0.189 & -0.069 & -0.055 & 0.260 \\
\hline$\Omega_{22}-$ Error & 2.014 & 1.931 & 0.556 & 1.625 & 1.542 & 0.523 \\
\hline Ln(marginal likelihood) & $-9,861.60$ & & & $-1,472.51$ & & \\
\hline Burn-in iterations & 500 & & & 500 & & \\
\hline Gibbs iterations & 5,000 & & & 5,000 & & \\
\hline Contexts & 31 & & & 26 & & \\
\hline$n$ & 21,927 & & & 3,902 & & \\
\hline \multicolumn{7}{|c|}{$\begin{array}{l}\text { Note: Uninformative prior distributions are used for all parameters. Post Mean denotes the posterior mean, Post Median the posterior median, and Post } \\
\text { StD the posterior standard deviation. The models are estimated using Markov chain Monte Carlo (MCMC). See the Appendix for a discussion of estimation } \\
\text { issues. The full data set contains all civil rights roll calls. For some votes, however, the theoretical assumption that the alternative is to the left of the status } \\
\text { quo }(A<Q) \text { does not hold. The results presented here are for the subset of the full data set when members are voting for the liberal alternative. This } \\
\text { eliminates three Senate and four House contexts from the analysis. The substantive results are robust to this restriction. }\end{array}$} \\
\hline
\end{tabular}

at the replication website, the results are robust to other prior specifications. This is expected, given the large sample size.

The specific approach employed to estimate the model is a type of Markov chain Monte Carlo (MCMC) estimation algorithm called the Gibbs sampler (see Gelman et al. 1995; Jackman 2000). This strategy allows one to draw inferences about all parameters in the model conditioned on the data, even with a small number of decision contexts. In practice, one uses diffuse priors, which in turn do not contribute substantively to the analysis (Jackman 2000; Western 1998). Given conjugate priors, the full conditional distributions take standard forms (Albert and Chib 1993; Lindley and Smith 1972): $\left\{\beta_{k}\right\} \mid y,\left\{z_{i, k}\right\}, \alpha, \Omega$ is multivariate Normal for all $k$, $\left\{z_{i, k}\right\} \mid y,\left\{\beta_{k}\right\}, \alpha, \Omega$ are truncated univariate Normal for all $i$ and $k, \alpha \mid y,\left\{z_{i, k}\right\},\left\{\beta_{k}\right\}, \Omega$ is multivariate Normal, and $\Omega^{-1} \mid y,\left\{z_{i, k}\right\},\left\{\beta_{k}\right\}, \alpha$ is Wishart.

As suggested by an anonymous reviewer, biases may enter the analysis by including data for which the assumption that the alternative is left of the status quo $A<Q$ does not hold. This coding convention was employed to maximize the size of the sample, particularly the number of decision contexts. To test the robustness of the results, I reestimated the models after purging the cases in which this condition does not hold. The results for hierarchical probit models for both the House and Senate are reported in Table A-1. Note that the substantive conclusions reached in the article do not change under this specification.

\section{REFERENCES}

Albert, James H., and Siddhartha Chib. 1993. "Bayesian Analysis of Binary and Polychotomous Response Data." Journal of the American Statistical Association 88 (June): 669-79.

Arnold, R. Douglas. 1990. The Logic of Congressional Action. New Haven, CT: Yale University Press.

Austen-Smith, David. 1987. "Sophisticated Sincerity: Voting Over Endogenous Agendas." American Political Science Review 81 (December): $1323-30$.

Bartels, Larry M. 1996. "Pooling Disparate Observations." American Journal of Political Science 40 (August): 905-42.
Belknap, George M. 1958. "A Method for Analyzing Legislative Behavior." Midwest Journal of Political Science 2 (November): 377-402.

Bianco, William T. 1994. Trust: Representatives and Constituents. Ann Arbor: University of Michigan Press.

Black, Henry Campbell. 1991. Black's Law Dictionary. 6th ed. St. Paul, MN: West.

Calvert, Randall L., and Richard F. Fenno, Jr. 1994. "Strategy and Sophisticated Voting in the Senate." Journal of Politics 56 (May): 349-76.

Clausen, Aage R. 1973. How Congressmen Decide: A Policy Focus. New York: St. Martin's.

Cleveland, William S. 1993. The Elements of Graphing Data. Murray Hill, NJ: AT\&T Bell Laboratories.

Congressional Quarterly. 1953-92. Congressional Quarterly Almanac, vols. 9-48. Washington, DC: Congressional Quarterly Press.

Denzau, Arthur, William Riker, and Kenneth Shepsle. 1985. "Farquharson and Fenno: Sophisticated Voting and Home Style." American Political Science Review 79 (December): 1117-34.

Downs, Anthony. 1957. An Economic Theory of Democracy. New York: Harper \& Row.

Efron, Bradley, and Carl Morris. 1973. "Combining Possibly Related Estimation Problems.” Journal of the Royal Statistical Society B 35 (3): $379-421$.

Enelow, James, and Melvin Hinich. 1984. The Spatial Theory of Voting: An Introduction. Cambridge: Cambridge University Press.

Enelow, James M., and David Koehler. 1980. "The Amendment in Legislative Strategy: Sophisticated Voting in the U.S. Congress." Journal of Politics 42 (May): 396-413.

Epstein, Lee, and Carol Mershon. 1996. "Measuring Political Preferences." American Journal of Political Science 40 (February): 261-94.

Eskridge, William N. 1991. "Overriding Supreme Court Statutory Interpretation Decisions." Yale Law Journal 101 (November): 331-417.

Fenno, Richard F., Jr. 1973. Congressmen in Committees. Boston: Little Brown.

Fiorina, Morris P. 1974. Representatives, Roll Calls, and Constituencies. Lexington, MA: Lexington Books.

Gelman, Andrew, John B. Carlin, Hal S. Stern, and Donald B. Rubin. 1995. Bayesian Data Analysis. London: Chapman \& Hall.

Green, Donald P., and Ian Shapiro. 1994. Pathologies of Rational 
Choice Theory: A Critique of Applications in Political Science. New Haven, CT: Yale University Press.

Greene, William. 1997. Econometric Analysis. 3d ed. Upper Saddle River, NJ: Prentice-Hall.

Inter-university Consortium for Political and Social Research, and Congressional Quarterly, Inc. 1997. United States Congressional Roll Call Voting Records, 1789-1994 [computer file] (Study \#0004). Ann Arbor, MI: Inter-university Consortium for Political and Social Research/Washington, DC: Congressional Quarterly, Inc. [producers]. Ann Arbor, MI: Inter-university Consortium for Political and Social Research [distributor].

Jackman, Simon. 2000. "Estimation and Inference via Bayesian Simulation: An Introduction to Markov Chain Monte Carlo." American Journal of Political Science 44 (April): 369-98.

Jones, Bradford S., and Marco R. Steenbergen. 1997. "Modeling Multilevel Data Structures." Paper presented at the annual meeting of the Political Methodology Section of the American Political Science Association.

Kass, Robert E., and Adrian E. Raftery. 1995. "Bayes Factors." Journal of the American Statistical Association 90 (June): 773-95.

Kau, James B., and Paul H. Rubin. 1979. "Self-Interest, Ideology, and Logrolling in Congressional Voting." Journal of Law \& Economics 22 (October): 365-84.

Kingdon, John W. 1989. Congressmen's Voting Decisions. 3d ed. Ann Arbor: University of Michigan Press.

Krehbiel, Keith, and Douglas Rivers. 1990. "Sophisticated Voting in Congress: A Reconsideration." Journal of Politics 52 (August): 548-78.

Lindley, D. V., and A. F. M. Smith. 1972. "Bayes Estimates for the Linear Model." Journal of the Royal Statistical Society B 34 (1): $1-41$.

Marks, Brian A. 1989. A Model of Judicial Influence on Congressional Policymaking: Grove City College v. Bell (1984). Ph.D. diss. Washington University, St. Louis.

Martin, Andrew D. 1998. Strategic Decision Making and the Separation of Powers. Ph.D. diss., Washington University, St. Louis.

Mayhew, David R. 1974. Congress: The Electoral Connection. New Haven, CT: Yale University Press.

McCormick, James M., and Michael Black. 1983. "Ideology and Senate Voting on the Panama Canal Treaties." Legislative Studies Quarterly 8 (February): 45-63.

McKelvey, Richard D. 1979. "General Conditions for Global Intransitivities in Formal Voting Models.” Econometrica 47 (September): 1085-112.
Miller, Warren E., and Donald E. Stokes. 1963. "Constituency Influence in Congress." American Political Science Review 57 (March): 45-56.

Mouw, Calvin J., and Michael B. MacKuen. 1992. "The Strategic Agenda in Legislative Politics." American Political Science Review 86 (March): 87-105.

Murphy, Walter F. 1964. Elements of Judicial Strategy. Chicago: University of Chicago Press.

Poole, Keith T., and Howard Rosenthal. 1989. United States Congressional Roll Call Voting Records, 1789-1987 [computer file] (Study \#9822). Pittsburgh, PA: Howard L. Rosenthal and Keith T. Poole, Carnegie Mellon University, Graduate School of Industrial Administration [producers], 1991. Ann Arbor, MI: Inter-university Consortium for Political and Social Research [distributor], 1996.

Poole, Keith T., and Howard Rosenthal. 1997. Congress: A PoliticalEconomic History of Roll-Call Voting. Oxford: Oxford University Press.

Richardson, Lilliard E., and Michael E. Munger. 1990. "Shirking, Representation, and Congressional Behavior: Voting on the 1983 Amendments to the Social Security Act." Public Choice 67 (October): 11-33.

Rodríguez, Germán, and Noreen Goldman. 1995. "An Assessment of Estimation Procedures for Multilevel Models with Binary Responses." Journal of the Royal Statistical Society B 158 (1): 73-89.

Rosenberg, Gerald N. 1992. "Judicial Independence and the Reality of Political Power." Review of Politics 54 (Summer): 369-98.

Segal, Jeffrey A., Charles M. Cameron, and Albert D. Cover. 1992. "A Spatial Model of Roll Call Voting: Senators, Constituents, Presidents, and Interest Groups in Supreme Court Confirmations." American Journal of Political Science 36 (February): 96121.

Segal, Jeffrey A., Richard J. Timpone, and Robert M. Howard. 2000. "Buyer Beware? Presidential Success through Supreme Court Appointments." Political Research Quarterly 53 (September): 55773.

Segal, Jeffrey A., and Harold J. Spaeth. 1993. The Supreme Court and the Attitudinal Model. Cambridge: Cambridge University Press.

Volden, Craig. 1998. "Sophisticated Voting in Supermajoritarian Settings." Journal of Politics 60 (February): 149-73.

Western, Bruce. 1998. "Causal Heterogeneity in Comparative Research: A Bayesian Hierarchical Modelling Approach." American Journal of Political Science 42 (October): 1233-59. 